\title{
Dewan Pendidikan Dalam Meningkatkan Mutu Pendidikan Di Kabupaten Rejang Lebong
}

\author{
Lukman Asha \\ Institut Agama Islam Negeri (IAIN) Curup, Indonesia \\ asha.lukman@gmail.com
}

\begin{abstract}
Improving the quality of education is the responsibility of all parties. One of the institutions carrying out this mandate in an area is the Education Council. This study aims to find out how the role of the Education Council in Rejang Lebong Regency in improving the quality of education so far. Through observation and interviews, it was found that the role of the Education Council in improving the quality of education in Rejang Lebong Regency was as follows: (a) consideration in determining and implementing education policies, (b) supporting both tangible financial, thought and energy in the implementation of education (c) controllers in the context of transparency and accountability in the administration and output of education, (d) mediators between the government and the Regional People's Representative Council (DPRD) with the community.

Keywords : Role, Education Council, Quality of Education, Rejang Lebong

Abstrak: Peningkatan mutu pendidikan merupakan tanggungjawab semua pibak. Salah satu lembaga yang mengemban amanah ini di sebuab daerah adalah Dewan Pendidikan. Penelitian ini bertujuan untuk. mengetahui bagaimana peran Dewan Pendidikan di Kabupaten Rejang Lebong dalam meningkatkan mutu pendidikan selama ini. Melalui observasi dan wawancara, ditemukan babwa babwa peran Dewan Pendidikan dalam meningkatkan mutu pendidikan di Kabupaten Rejang Lebong adalab sebagai berikut: (a) pemberi pertimbangan dalam penentuan dan pelaksanaan kebijakan pendidikan, (b) pendukung baik. berwujud financial, pemikiran maupun tenaga dalam penyelenggaraan pendidikan, (c) pengontrol dalam rangkea transparansi dan akuntabilitas penyelenggaraan dan keluaran pendidikan, (d) mediator antara pemerintab dan Dewan Perwakilan Rakyat Daerah (DPRD) dengan masyarakat.
\end{abstract}

\section{Pendahuluan}

Kata Kunci : Peran, Dewan Pendidikan, Mutu Pendidikan, Rejang Lebong

Dewan Pendidikan memegang peran yang sangat penting dalam proses peningkatan kualitas pendidikan. Peningkatan kualitas pendidikan merupakan suatu proses yang terintegrasi dengan proses peningkatan kualitas sumber daya manusia itu sendiri. Menyadari pentingnya proses peningkatan sumber daya manusia, maka pemerintah, kalangan swasta telah terus berupaya mewujudkan amanat tersebut melalui berbagai usaha pembangunan pendidikan yang berkualitas antara lain melalui pengembangan dan perbaikan kurikulum dan sistem evaluasi, perbaikan sarana prasarana pendidikan, pengembangan dan pengadaan materi ajar, serta pelatihan bagi guru dan tenaga kependidikan lainnya.

Undang-undang Nomor 20 tahun 2003 pasal 1 ayat 2 diamanatkan bahwa: "Sumber daya pendidikan adalah pendukung dan penunjang pelaksanaan pendidikan yang terwujud sebagai tenaga, dana, sarana, dan prasarana yang tersedia atau diadakan dan didayagunakan keluarga, masyarakat, peserta didik dan pemerintah, baik sendiri-sendiri maupun bersama-sama."

Kenyataan upaya yang dilakukan pemerintah tersebut belum cukup berarti dalam meningkatkan kualitas pendidikan. Salah satu indikator kekurang

1Undang-undang No. 20 tahun 2003 Sistem Pendidikan Nasional, pasal 1 ayat 2. 
berhasilan ini memperlihatkan antara lain dengan nilai ujian nasional (UN) siswa yang tidak memperlihatkan kenaikan yang berarti bahkan boleh dikatakan konstan dari tahun ke tahun, kecuali pada beberapa sekolah dengan jumlah yang relative sangat kecil. Ada dua faktor yang menjelaskan mengapa upaya perbaikan mutu pendidikan selama ini kurang atau tidak berhasil, pertama; strategi pembangunan pendidikan yang selama ini lebih bersifat input-oriented, strategi yang demikian lebih berstandar kepada asumsi bahwa bilamana semua inputpendidikan telah dipenuhi, seperti penyediaan buku-buku (materi ajar) dan alat belajar lainnya, penyediaan sarana pendidikan, pelatihan guru dan tenaga kependidikan lainnya, maka secara otomatis (materi ajar) dan alat belajar lainnya, penyediaan sarana pendidikan, pelatihan guru dan tenaga kependidikan lainnya, maka secara otomatis lembaga pendidikan (sekolah) akan menghasilkan ouput (keluaran) yang bermutu sebagaimana yang diharapkan. Ternyata strategi inputoutput yang dikenalkan oleh teori education production function tidak berfungsi sepenuhnya di lembaga pendidikan (sekolah) melainkan hanya terjadi dalam institusi ekonomi dan industri.Kedua; pengelolaan pendidikan selama ini lebih bersifat macro-oriented, diatur oleh jajaran birokrasi di tingkat pusat.Akibatnya, banyak faktor yang diproyeksikan di tingkat makro (pusat) tidak terjadi atau tidak berjalan sebagaimana mestinya di tingkat mikro (sekolah).Atau dengan singkat dapat dikatakan bahwa kompleksitasnya cakupan permasalahan pendidikan, kondisi lingkungan sekolah dan bervariasinya kebutuhan siswa dalam belajar serta aspirasi masyarakat terhadap pendidikan, seringkali tidak dapat terpikirkan secara utuh dan akurat oleh birokrasi pusat.

Pendidikan nasional mempunyai tujuan, seperti yang telah diungkapkan di atas tentu tidak mudah untuk mewujudkan, karena pendidikan merupakan kegiatan dinamis yang selalu berubah sesuai dengan perubahan zaman.Untuk itu pendidikan selalu memerlukan upaya perbaikan dan peningkatan sejalan dengan kebutuhan dan tuntutan kehidupan masyarakat.

Salah satu upaya perbaikan pendidikan adalah dengan memperbaiki pengelolaan pendidikan, karena pengelolaan pendidikan diperlukan baik tingkat makro yaitu pada Kementeria Pendidikan Nasional, ditingkat mezzo yaitu pada Dinas Pendidkan Nasional Propinsi, Kabupaten dan di tingkat mikro yaitu pada perguruan tinggi dan sekolah.

Tahun 2001 merupakan awal berlakunya otonomi daerah di Indonesia, saat ini otonomi pendidikan merupakan salah satu bagian dari otonomi daerah itu sendiri mulai digulirkan meskipun secara bertahap.Sekaranglah waktunya bagi para ahli, praktisi dan pengamat pendidikan untuk bersama-sama memberdayakan pendidikan nasional.Perbincangan tentang pelaksanaan otonomi pendidikan seakan tak pernah berakhir.Hal ini disebabkan oleh karena persoalan yang belum terpecahkan di dalamnya.Ada dua isu besar yang mengiringi pelaksanaan otonomi pendidikan, yakni dimulai dari masa transisi 
desentralisasi pengelolaan pendidikan dan kecenderungan merosotnya hasil perkembangan pendidikan yang selama ini dicapai. Tak dapat ditolak, kedua isu ini akan mempengaruhi arah pendidikan nasional dimasa yang akan datang.

Masa transisi pendidikan mengharuskan diperlukannya landasan dasar pendidikan yang lebih demokratis, transparan, efisien dan melibatkan partisipasi masyarakat daerah.Dewan pendidikan dibentuk berdasarkan kesepakatan yang tumbuh dari akar budaya, sosio demografi dan nilai-nilai daerah setempat, sehingga lembaga tersebut bersifat otonom yang menganut azas kebersamaan menuju kearah peningkatan kualitas pengelolaan pendidikan di daerah yang diatur oleh Anggaran Dasar dan Anggaran Rumah Tangga. Ada keberagaman daerah dalam menyikapi diberlakukannya dua otonomi ini, ada daerah yang optimis dan pihak lain merasa pesimis. Daerah yang merasa pesimis lebih disebabkan adanya realitas kondisi daerahnya, khusus kemampuan masyarakat untuk menyelenggarakan pendidikan yang berbeda-beda.

Pelaksanaan pengelolaan pendidikan (khususnya sekolah) sangat rumit dan unik, terutama karena terbatasnya sumber-sumber pendukung yang diperlukan untuk penyelenggaraan pendidikan yang ideal.Hal ini memaksa para kepala sekolah selaku manajer pendidikan di sekolah dituntut untuk berusaha keras mencari, mempelajari dan menerapkan konsep-konsep, prinsip, metode dan teknik perencanaan yang jitu. ${ }^{2}$ Perencanaan pendidikan diawali dengan memperkirakan potensi sumber dana dan kekayaan yang akan tersedia untuk mencapai tujuan pendidikan sesuai dengan tingkatan tujuan yang ada dengan melibatkan orang tua murid dan masyarakat melalui lembaga yang secara khusus dibentuk untuk itu.

Studi pendahuluan di Dewan Pendidikan Kabupaten Rejang Lebong dilihat dari hasil dokumen yang berkenaan dengan lembaga pendidikan menyatakan bahwa sarana pendidikan khususnya yang menyangkut kekayaan sekolah pada umumnya sangat minim, dan hasil verifikasi menunjukkan bahwa paling tidak hanya $15 \%$ saja sarana sekolah pendidikan sekolah itu terpenuhi dan banyak lagi sekolah-sekolah yang dikategorikan kurang, hal ini mungkin terjadi karena beberapa hal yang salah satunya adalah sumber daya manusia di daerah dan sumber biaya yang masih sangat tergantung pada pemerintah pusat.

Lemahnya peranan kepala sekolah dalam mengelola lembaganya juga merupakan kendala terhadap kemajuan pendidikan, Fulan mengemukakan ada tiga faktor yang membuat lemahnya peranan kepala sekolah, yakni: 1) kepala sekolah memiliki otonomi yang sangat terbatas, 2) kepala sekolah kurang memiliki keterampilan untuk mengelola sekolah dengan baik, 3) kecilnya peran serta masyarakat dalam pengelolaan sekolah. ${ }^{3}$ Padahal sudah dijelaskan dalam

2Siwojo, Pendidikan Bermutu dan Ideal, Jakarta: Radar Jaya, 2005, h. 108.

${ }^{3}$ Fulan, Peranan Kepala Sekolah, Bandung: Pustaka Setia, 1997, h. 12. 
Peraturan Pemerintah No. 39 tahun 1992 tentang peran serta masyarakat dalam pendidikan nasional pada pasal 2: "Peran serta masyarakat berfungsi ikut memelihara, menumbuhkan, meningkatkan dan mengembangkan pendidikan nasional". 4

Bentuk peran serta masyarakat dalam pendidikan adalah; 1) pendirian dan penyelenggaraan satuan pada jalur pendidikan luar sekolah, pada semua jenis pendidikan kecuali pendidikan kedinasan, dan pada semua jenjang pendidikan dijalur sekolah, 2) pengadaan dan pemberian bantuan tenaga untuk melaksanakan atau membantu pelaksanaan pengajaran, pembimbingan dan/atau pelatihan peserta didik, 3) pengadaan dan pemberian bantuan tenaga ahli untuk membantu pelaksanaan kegiatan belajar mengajar dan/atau penelitian dan pengembangan, 4) pengadaan dan/atau penyelenggaraan program pendidikan yang belum diadakan dan/atau diselenggarakan oleh pemerintah untuk menunjang pendidikan nasional, 5) pengadaan dana dan pemberian bantuan yang dapat berupa wakaf, hibah, sumbangan, pinjaman, beasiswa dan bentuk lain yang sejenis, 6) pengadaan dan pemberian bantuan ruangan, gedung dan tanah untuk melaksanakan kegiatan belajar mengajar, 7) pengadaan dan pemberian bantuan buku pelajaran dan peralatan pendidikan untuk melaksanakan kegiatan belajar mengajar, 8) pemberian kesempatan magang atau latihan kerja, 9) pemberian bantuan manajemen bagi penyelenggaraan satuan pendidikan dan pengembangan berkenaan dengan penentuan kebijaksanaan dan/atau penyelenggaraan pengembangan pendidikan nasional, 11) pemberian bantuan kerjasama dalam kegiatan penelitian dan pengembangan, 12) keikutsertaan dalam program pendidikan dan/atau penelitian yang diselenggarakan oleh pemerintah di dalam dan/atau di luar negeri. ${ }^{5}$

Beberapa informasi tersebut di atas tergambar betapa kecilnya kontribusi masyarakat terhadap dunia pendidikan khususnya sekolah. Dengan keluarnya Undang-undang No. 22 tahun 1999 dan Undang-undang No. 25 tahun 2000 mencerminkan adanya kemauan Pemerintah pusat (Political Will) untuk mengurangi sentralisasi kekuasaan yang berlebihan dimasa lampau. Demikian halnya dalam perumusan kebijakan otonomi daerah khususnya dalam pengelolaan pendidikan yang meliputi aspek kelembagaan, kurikulum, sumber daya manusia, pembiayaan serta sarana dan prasarana, yang secara oprasional pihak sekolah diberi kewenangannya itu sekolah harus dibantu oleh masyarakat atau berbagai pihak yang berkepentingan (stakehorders). ${ }^{6}$

Pasli Jalal dan Dedi Supriadi mengatakan: "pendidikan dengan segala persoalannya tidak diatasi hanya oleh lembaga persekolahan. Untuk

\footnotetext{
${ }^{4}$ Departemen Pendidikan dan Kebudayaan, Peraturan Pemerintab No. 39 tahun 1992.

5 Indra Jati Sidi, Menuju Masyarakat Belajar: Menggagas Paradigma Baru Pendidikan, Jakarta: Alfa Beta, 2002, h. 113.

6Undang-undang No. 25 tahun 2000, tentang Peran Pemerintah dalam Pendidikan.
} 
melaksanakan program-programnya sekolah perlu mengundang berbagai pihak (keluarga, masyarakat, dan dunia usaha/industri untuk berpartisipasi secara aktif dalam berbagai program pendidikan lebih bermakna bagi sekolah, terutama bagi peningkatan mutu dan efektifitas pendidikan, partisipasi masyarakat tidak seharusnya hanya dalam bentuk dana, melainkan juga sumbangan pemikiran dan tenaga". 7

Bertitik tolak dari hal-hal di atas, maka pada awalnya konsepSchool Based Manajemen (SBM) ditawarkan untuk membangun sebuah pendidikan masa depan yang mandiri, otonom dan berpijak di atas kekuatan masyarakat serta berwawasan lingkungan dengan pemberian peran penting kepada masyarakat.

Otonomi daerah sesungguhnya memberi angin segar terhadap beberapa wilayah yang dianggap mampu dan layak untuk mengembangkan pendidikan karena ditunjang oleh kekayaan alam, budaya dan lain sebagainya, tetapi sebaliknya bagi daerah yang minim hal ini akan mempunyai permasalahan tersendiri. Dedi Supriadi menjelaskan bahwa: "melalui otonomi daerah, daerah memiliki kewenangan besar untuk mengambil keputusan dan mengimplementasikannya termasuk mempertanggungjawabkan hasilnya". ${ }^{8}$

Unsur yang ditempatkan bersama-sama di daerah, yakni kewenangan pengambilan keputusan, alokasi dan penggunaan dana serta akuntabilitas hasil, pengambilan keputusan pendidikan masa lalu banyak kewenangan bahkan halhal yang bersifat teknis tidak berada di daerah tetapi di pusat atau di propinsi, demikian pula keputusan penggunaan dana, namun sebagian besar akuntabilitas hasil diletakkan di daerah bahkan di sekolah. Hal ini yang menjadi salah satu sumber masalah yang terjadi dimasa lalu yang sentralistik.

Era otonomi ini mengharapkan sekolah untuk lebih bergerak secara mandiri dalam meningkatkan kinerja manajemen sekolah, seperti dijelaskan oleh Satori dan Fattah:

Kepentingan utama format otonomi sekolah adalah tampilnya kemandirian sekolah untuk meningkatkan kinerjanya sendiri, dengan mengakomodasi berbagai potensi sumber daya sekolah yang pada akhirnya ditujukan untuk meningkatkan mutu pendidikan dalam wujud mutu hasil belajar para siswa. ${ }^{9}$

Drury dan Levin melaporkan manajemen berbasis sekolah dengan Dewan sekolahnya mampu mewujudkan tata kerja yang lebih baik dalam empat hal berikut: 1) meningkatkan efisiensi penggunaan sumber daya dan penugasan staf, 2) meningkatkan profesionalisme guru, 3) munculnya gagasan baru dalam implementasi kurikulum, dan 4) meningkatnya mutu partisipasi

\footnotetext{
7Pasli Jalal dan Dedi Supriadi, Meningkatkan Mutu Pendidikan, Jakarta: Rosda Karya, 2004, h. 99.

${ }^{8}$ Dedi Supriadi, Otonomi Daerah dan Pendidikan, Materi Seminar Pendidikan tahun 2002.

${ }^{9}$ Satori dan Fattah, Otonomi Pendidikan, Jakarta: Grasindo, 2006, h. 9.
} 
masyarakat. ${ }^{10}$ Kondisi-kondisi tersebut dapat dipandang sebagai sesuatu yang sangat potensial untuk peningkatan kinerja dan hasil belajar peserta didik.

Lokasi kantor Dewan Pendidikan Kabupaten Rejang Lebong dengan alamat Jalan Letjen Soeprapto No. 125 Kelurahan Talang Rimbo Lama Curup. Bahwa Dewan Pendidikan berpartisipasi aktif dalam pengawasan dan pemberdayaan sekolah, perekrutan guru dan kepala sekolah, pengadaan sarana pendidikan dan meningkatkan kerja sama pemerintah masyarakat dan sekolah.

Dari pernyataan tersebut sehingga penulis tertarik untuk mengkaji lebih jauh tentang peranan Dewan Pendidikan di Kabupaten Rejang Lebong.

\section{Hasil Penelitan}

\section{a. Peran Dewan Pendidikan dalam Pengawasan Pemberdayaan Sekolah}

Dewan Pendidikan berfungsi mendorong tumbuhnya perhatian dan komitmen masyarakat terhadap kualitas penyelenggaraan pendidikan khususnya kualitas manajemen sekolah dan layanan belajar di sekolah. Dewan Pendidikan melakukan kerjasama dengan masyarakat (perorangan/organisasi) pemerintah, dan DPRD berkenaan dengan penyelenggaraan pendidikan yang bermutu. Menampung dan menganalisis aspirasi, ide, tuntutan dan berbagai keperluan pendidikan yang diajukan oleh masyarakat.

Peneliti mengajukan pertanyaan kepada Ketua Dewan Pendidikan untuk mengetahui lebih jelas terhadap pengawasan pemberdayaan sekolah "Kegiatan apa saja yang telah dilakukan oleh Dewan Pendidikan dalam rangka pelaksanaan pengawasan pendidikan" hasil jawaban yang didapatkan adalah sebagai berikut:

Pengawasan yang dilakukan adalah ikut melakukan pengawasan pelaksanaan kebijakan pendidikan diantaranya seperti Bantuan Operasional Sekolah (BOS), Dana Alokasi Khusus (DAK), dan Ujian Nasional (UN). Hal lain yang dilakukan adalah memberikan saran kepada pejabat Pendidikan Nasional (Ka. Diknas) dan Kepala Sekolah agar DAK tidak diborongkan (dikerjakan pihak ketiga), namun masih ada beberapa sekolah yang melakukan hal tersebut. ${ }^{11}$

Hasil wawancara diatas dapat disimpulkan bahwa Dewan Pendidikan memperhatikan akan pemberdayaan sekolah-sekolah yang ada sehingga memberikan masukan, pertimbangan, dan rekomendasi kepada pemerintah daerah/DPRD mengenai; 1) kebijakan dan program pendidikan; 2) kriteria kinerja daerah dibidang pendidikan; 3) kriteria tenaga kependidikan khususnya guru, tutor, konselor, dan kepala satuan pendidikan; 4) kriteria fasilitas pendidikan; dan 5) hal ini berkaitan dengan pendidikan. Mengacu pada tujuan, peran, dan fungsi Dewan Pendidikan, power intelektualitasnya harus sama kuat

\footnotetext{
10Drury dan Levin, Manajemen Berbasis Sekolah, Jakarta: Rineka Cipta, 2001, h. 98.

${ }^{11}$ Wawancara dengan Bapak Iskandar Ketua DP, tanggal 7 Agustus 2015.
} 
dengan parlemen dan eksekutif sehingga diantara mereka tejadi tawar-menawar yang seimbang dalam kebijakan pendidikan.

Dewan Pendidikan sebagai pemberi pertimbangan terhadap Dinas Pendidikan Kabupaten Rejang Lebong dengan dibuktikan dengan hasil wawancara peneliti dengan Ketua Dewan Pendidikan Kabupaten Rejang Lebong, "kegiatan apa yang telah dilakukan oleh Dewan Pendidikan dalam rangka pelaksanaan pemberi masukan/pertimbangan" jawaban dari Ketua Dewan Pendidikan adalah sebagai berikut:

Dewan Pendidikan memberikan saran dan masukan kepada Diknas agar kegiatan dilaksanakan sesuai juknis serta melakukan kegiatan penggalangan dana dengan instansi terkait atau terhadap donatur maupun wali siswa yang dipandang berkemampuan untuk memberi beasiswa murid dan guru yang berprestasi. ${ }^{12}$

Pengembangan sumber daya manusia (SDM) adalah proses peningkatan kemampuan manusia agar mampu melakukan pilihan-pilihan. Penelitian ini memusatkan perhatian pada pemerataan dalam peningkatan kemampuan manusia sebagai personil dalam organisasi termasuk dalam lembaga pendidikan.Rumusan tersebut menunjukkan bahwa pengembangan sumber daya manusia tidak hanya sekedar meningkatkan kemampuan, tetapi juga menyangkut pemanfaatan kemampuan tersebut.

Penentuan kepemimpinan baik lembaga instansi di bidang pendidikan maupun pemimpin sekolah DewanPendidikan memberi suatu pandangan yang menyatakan adanya kepentingan dalam pengembangan personil dinyatakan secara konseptual pengembangan bukanlah sesuatu yang diperlukan sekolah bagi guru tetapi merupakan hal yang harus dilakukan oleh dirinya sendiri. Pada dasarnya pengembangan berorientasi pada pertumbuhan.

\section{b. Peran Dewan Pendidikan dalam Perekrutan Guru dan Kepala Sekolah}

Dewan Pendidikan menata dan memperhatikan keadaan guru dalam perekrutan guru untuk memenuhi kebutuhan sekolah yang diharapkan, disekolah masing-masing kemudian mengadakan konsultasi kepada dinas pendidikan dan dilanjutkan kepada pemerintah daerah Kabupaten Rejang Lebong. Hasil wawancara peneliti dengan anggota Dewan Pendidikan dalam perekrutan guru dan kepala sekolah "apakah Dewan Pendidikan mempunyai wewenang dalam perekrutan guru dan Kepala Sekolah?” jawaban yang peneliti dapatkan adalah:

Untuk wewenang dan perekrutan guru dan Kepala Sekolah Dewan Pendidikan tidak mempunyai hak seutuhnya itu semua menjadi hak dan tanggungjawab pemerintah daerah, namun didalam perekrutan tersebut Dewan Pendidikan memiliki hak untuk memberi masukan tentang guru

12 Wawancara dengan Bapak Arlan, S.Pd., MM, tanggal 7 Agustus 2015. 
dan kriteria guru/kepala sekolah yang patut dipertimbangan dalam prekrutan dimaksud kepada Diknas dan pemerintah Kabupaten Rejang Lebong. ${ }^{13}$

Kebutuhan yang diperlukan akan pengadaan guru dan kepala sekolah tersebut tentunya berdasarkan kriteria dari guru yang bersangkutan begitu juga pada perekrutan kepala sekolah, kepala sekolah yang layak dipilih yang memiliki sikap professional dalam bidang pekerjaannya kriteria tersebut adalah: 1) memiliki landasan pengetahuan yang kuat, 2) berdasarkan atas kompetensi individual, 3) memiliki sistem seleksi dan sertifikasi, 4) adanya kerjasama dan kompetensi yang sehat antar sejawat, 5) adanya kesadaran professional yang tinggi, 6) memiliki prinsip-prinsip Etik, 7) memiliki sistem sanksi profesi, 8) adanya militasi individual, dan 9) memiliki organisassi profesi.

Untuk mengetahui keadaan guru dan Kepala Sekolah yang dianggap mampu mengelola dan membimbing semua personel sekolah Dewan Pendidikan mengadakan survey secara langsung dilokasi sekolah yang membutuhkan guru dan kepala sekolah sebagaimana hasil wawancara peneliti dengan anggota Dewan Pendidikan "apakah Dewan Pendidikan mengadakan survey dilapangan untuk mengetahui kebutuhan guru dan kepala sekolah?" jawab yang didapatkan adalah:

Benar, dalam pengadaan guru dan kepala sekolah yang diharapkan pemerintah, dewan pendidikan mengadakan survey terlebih dahulu, supaya dalam penempatan kerja guru atau kepala sekolah nantinya tidak terjadi kesalahan sehingga membuat tugas tambahan setelah penetapan atau membuat kondisi sekolah kurang kondusip. ${ }^{14}$

Kepala Sekolah dan guru adalah jabatan yang tidak bisa diisi oleh orangorang tanpa didasarkan ataspertimbangan formal dan rasional, siapapun yang diangkat menjadi kepala sekolah, harus ditentukan melalui prosedur serta persyaratan-persyaratan tertentu. Oleh Karena itu jabatan-jabatan kepala sekolah adalah jabatan formal sebab pengangkatannya melalui suatu proses dan suatu prosedur yang didasarkan atas peraturan yang berlaku.

Kepala sekolah dinyatakan berhasil jika memahami keberadaan sekolah sebagai organisasi yang kompleks, serta mampu melaksanakan tugasnya sebagai seseorang yang diberi tanggung jawab untuk memimpin sekolah. Kepala sekolah harus mengetahui tugas yang akan menentukan warna bagi sekolah yang dipimpinnya. Betapa pentingnya peranan kepala sekolah untuk mencapai tujuan.Atas dasar hal tersebut kepala sekolah berperan sebagai kekuatan sentral yang menjadi penggerak jalannya aktivitas sekolah.

\footnotetext{
13 Wawancara dengan Bapak H. Nofri, S.Pd., MM, Sekre. DP.tanggal 10 Agustus 2015

${ }^{14}$ Wawancara dengan Bapak Mahedi, SP., anggota DP, tanggal 11 Agustus 2015.
} 


\section{c. Peran Dewan Pendidikan dalam Pengadaan Sarana Pendidikan}

Sarana dan prasarana pendidikan merupakan aspek penting yang dilakukan oleh ketua Dewan Pendidikan dalam rangka pengadaan sarana dan prasarana tersebut sesuai dengan kebutuhan proses pembelajaran. Kinerja Ketua Dewan Pendidikan dalam merumuskan rencana pengadaan sarana dan prasarana pendidikan di sekolah untuk sekolah yang tidak memiliki jaringan atau akses dengan kalangan stakeholder, perencanaan sarana dan prasarana pembelajaran tersebut hanya mengandalkan dari anggaran yang bersumber dari pemerintah, yang dalam hal ini hanya ditujukan melalui cabang Dinas Pendidikan setempat untuk di rekomendasikan ke Dinas Pendidikan kabupaten/kota maka item-item pengadaan sarana dan prasarana tersebut relative lebih lengkap. Misalnya yang dilakukan oleh Dewan Pendidikan, perencanaan pengadaan sarana dan prasarana sekolah tidak hanya ditujukan kepada Dinas Pendidikan Kabupaten/Kota, akan tetapi dibicarakan dengan pengurus Dewan Pendidikan. Dengan pola tersebut, bahwa perencanaan sarana dan prasarana pendidikan tersbut relatif lebih lengkap, karena sumber pembiayaan dan pengadaannya tidak hanya mengandalkan dari pemerintah, akan tetapi dapat digali dari pihak lain, seperti dari kalangan pengusaha yang termasuk ke dalam pengurus Dewan Pendidikan.

Proses penyusunan perencanaan pengadaan sarana dan prasarana sekola tersebut, dilakukan dengan menganalisis kebutuhan-kebutuhan apa yang diperlukan dalam proses belajar mengajar di sekolah. Hasil dari analisis tersebut, kemudian diinventarisir untuk kemudian dibawa ke dalam forum rapat bersama dengan pengurus Dewan Pendidikan. Dalam rapat tersebut, maka dilakukan proses audit untuk merumuskan skala prioritas apa yang perlu diadakan untuk menyangkut sarana prasarana sekolah tersebut. Menurut ketua Dewan Pendidikan, ada beberapa pertimbangan yang dijadikan dasar dalam merumuskan skala prioritas perencanaan pengadaan sarana dan prasarana sekolah, antara lain: 1) kondisi keuangan yang dimiliki oleh masing-masing sekolah; 2) sumber potensial sumber keuangan (dana) yang diperlukan untuk membiayai pengdaan sarana dan prasarana sekolah yang diperlukan; 3) urgensinitas (pentingnya) sarana dan prasarana sekolah terhadap peningkatan pelayanan mutu pendidikan.

Kegiatan selanjutnya, setelah dilakukan audit terhadap daftar rencana pengadaan sarana dan prasarana tersebut sesuai dengan prinsip skala prioritas, maka ketua Dewan Pendidikan melakukan pengadaan sarana dan prasarana sekolah yang biasanya disatukan dalam rencana anggaran pendapatan belanja sekolah (RAPBS). Dalam RAPBS tersebut biasanya digambarkan item-item pengadaan sarana prasarana sekolah beserta dengan rincian biayanya.

Setelah program sarana prasarana sekolah dibangun, maka kepala sekolah mengusulkan pengadaan item-item sarana prasarana tersebut sesuai dengan yang direncanakan.Dalam tahap ini pula, nampak adanya perbedaan pada masing- 
masing sekolah dasar.Untuk sekolah dasar yang belum memiliki jaringan kerjasama dengan kalangan pengusaha dan stakeholder lainnya, maka pengadaan sarana prasarana sekolah hanya ditujukan kepada instansi pemerintah, yang dalam hal ini adalah Dinas Pendidikan dan Kebudayaan Kabupaten Rejang Lebong.

Meskipun bantuan tersebut lebih ditekankan pada peningkatan sumber daya manusia (guru dan Ketua Dewan Pendidikan) melalui kegiatan kelompok guru (KKG) dan kegiatan kelompok kepala sekolah (KKKS). Dalam rincian alokasi pengelolaan keuangan yang bersumber dari biaya evaluasi program (BEP)/ biaya oprasional sekolah (BOS), pihak sekolah dapat menyisikan pengadaan alat tulis sekolah yang mana hal tersebut sebenarnya dapat dimanfaatkan untuk meningkatkan kualitas proses belajar mengajar. Dengan adanya bantuan tersebut, diakui oleh Dewan Pendidikan, dapat membantu atau mengatasi minimnya anggaran pembiayaan yang bersumber dari pemerintah.

Partisipasi masyarakat dan kalangan pengusaha yang terlibat dalam kepengurusan Dewan Pendidikan, misalnya menurut pengakuan Dewan Pendidikan pada sekolah yang bersangkutan, dikatakan bahwa pengadaan paving blok, dan perangkat computer.

\section{d. Peran Dewan Pendidikan dalam Peningkatan Kerjasama Masyarakat, Pemerintah dan Lembaga Pendidikan}

Peranan keberadaan Dewan Pendidikan bertumpu pada landasan partisipasi masyarakat dalam meningkatkan kualitas penyelenggaraan pendidikan di daerah. Adapun peranan yang dijalankan Dewan Pendidikan adalah: a) pemberi pertimbangan dalam penentuan dan pelaksanaan kebijakan pendidikan; b) pendukung, baik berwujud financial, pemikiran maupun tenaga dalam penyelenggaraan pendidikan; c) pengontrol dalam rangka transparansi dan akuntabilitas penyelenggaraan dan keluaran pendidikan; d) mediator antara pemerintah dan Dewan Perwakilan Rakyat Daerah dengan masyarakat.

Hasil wawancara peneliti dengan anggota Dewan Pendidikan Kabupaten Rejang Lebong; "kegiatan apa saja yang telah dilakukan Dewan Pendidikan dalam pelaksanaan mediator?" jawaban yang didapatkan adalah:

Kegiatan yang dilakukan selain observasi, koordinasi, memenuhi undangan apabila diundang untuk menghadiri kegiatan-kegiatan sekolah dan instansi lain, monitoring enam bulan sekali, minimal satu tahun sekali, dengan harapan dapat memberikan masukan dan menerima aspirasi yang ingin disampaikan kepada lembaga lainnya. ${ }^{15}$

Pendidikan dalam konteks pembangunan daerah, seharusnya mampu memberikan respon yang tepat terhadap tuntutan pembangunan daerah dan aspirasi masyarakat yang dilayaninya.Hal ini berarti bahwa rumusan dan

15Wawancara dengan Bapak Drs. Syaiful, MM, anggota DP, tanggal 11 Agustus 2015. 
kebijakan serta keputusan yang dibuat hendaknya memperhatikan aspirasi yang berkembang didaerah.Dewan Pendidikan sebagai suatu badan yang mewakili aspirasi masyarakat memberi pertimbangan (advisory agency) agar pendidikan menjadi prioritas utama pembangunan daerah.Kemudian dalam penentuan dan pelaksanaan kebijakan pendidikan untuk mendekatkan stakeholder pendidikan agar akses terhadap perumusan kebijakan dan pembuatan keputusan yang menyangkut penyelenggaraan pendidikan adalah sangat beralasan.Keempat peranan Dewan Pendidikan ini sebenarnya dapat dijabarkan fungsi Dewan Pendidikan yang diimplementasikan dalam program kerjanya. Dengan kata lain fungsi Dewan Pendidikan merupakan penjabaran dari peran Dewan Pendidikan untuk mencapai tujuan.

Peranan Dewan Pendidikan dalam penyelenggaraan pendidikan dari pendidikan dapat dideskripsikan sebagai berikut: 1) dapat mengintensifkan kegiatan serta melibatkan diri dalam kegiatannya sesuai dengan wewenang yang telah disepakati; 2) ikut merumuskan desain pembelajaran yang kreatif dan inovatif sehingga dapat memberikan konstribusi kearah peningkatan mutu pendidikan; 3) ikut merumuskan dan melaksanakan berbagai program unggulan sekolah.

Hasil penelitian berdasarkan dokumentasi Dinas Pendidikan Kabupaten Rejang Lebong, digambarkan dengan bagan yang berkenaan dengan hubungan Dewan Pendidikan dengan instansi terkait Kabupaten Rejang Lebong. 


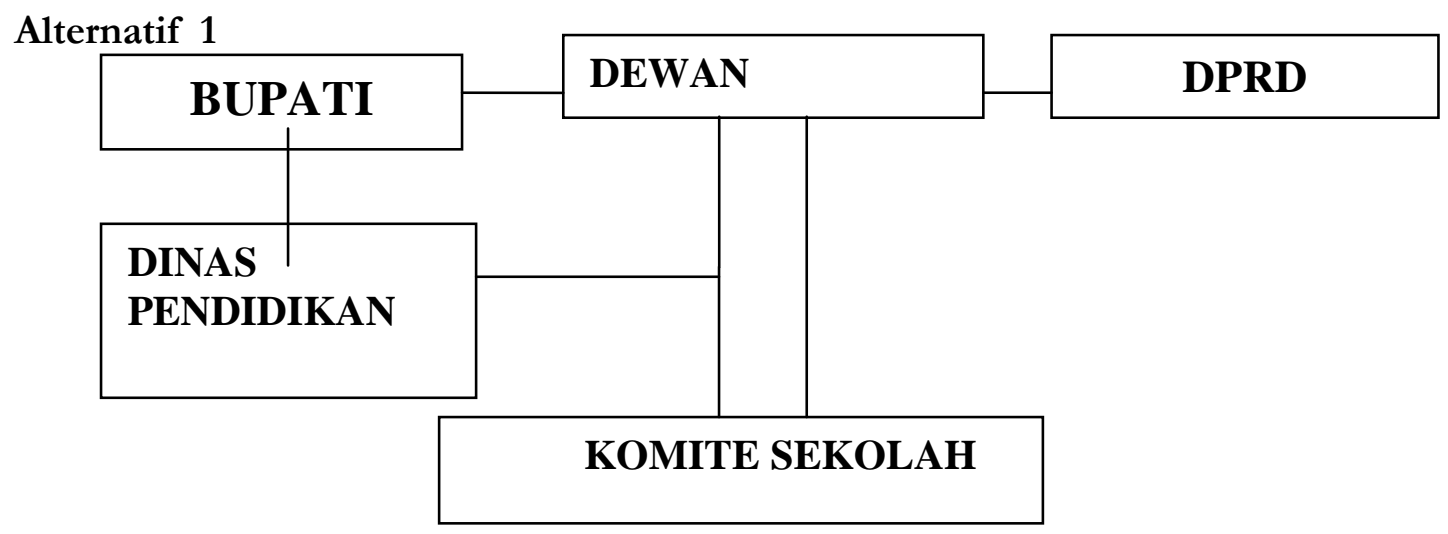

\section{Keterangan:}

hubungan Instruksi

hubungan kordinasi

\section{Gambar 1}

Hubungan Dewan Pendidikan dengan Instansi Terkait di Kabupaten Rejang Lebong

Alasan Dewan Pendidikan menentukan alternative 1 (satu) karena mempermudah tata hubungan yang bersifat koordinatif dengan pemerintah daerah, DPRD, Dinas Pendidikan serta komite-komite sekolah dalam peningkatan mutu pendidikan di suatu kabupaten atau kota. Jika alternative 1 (satu) diatas tidak dapat dilakukan maka tata hubungan akan dilakukan dengan alternative 2 (dua), seperti yang digambarkan dibawah ini.

\section{Alternatif 2}

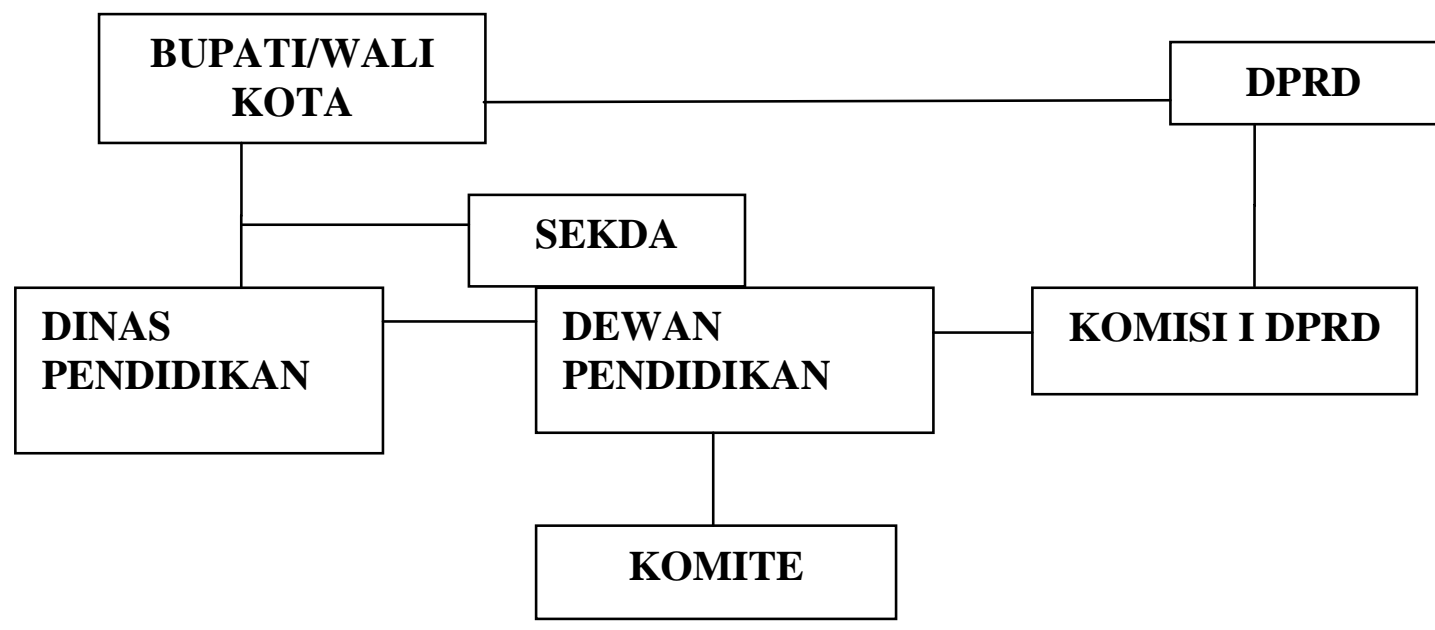




\section{Keterangan:}

hubungan Instruksi

hubungan kordinasi

Gambar 2

Hubungan Dewan Pendidikan dengan Instansi Terkait di Kabupaten Rejang Lebong

Gambar dari alternative 2 (dua) ini menjelaskan tentang tata hubungan Pemerintah Daerah dengan Sekda, Dinas Pendidikan, dan DPRD dan bersifat instruksi kemudian Dinas Pendidikan melakukan tata hubungan dengan Komisi E DPRD serta Komite-komite sekolah yang bersifat koordinatif.

\section{Pembahasan}

\section{a. Peran Dewan Pendidikan dalam Pengawasan Pemberdayaan Sekolah}

Dewan Pendidikan dalam pemberdayaan sekolah dituntut adanya pengawasan atau evaluasi dan monitoring baik petugas provinsi maupun petugas kabupaten/kota. Sebagaimana menurut Dirjen Pendidikan dasar dan menengah dalam Depdiknas menyatakan melalui monitoring dan evaluasi sekolah akan mengetahui apakah pelaksanaan sekolah sesuai dengan program yang direncanakan. ${ }^{16}$ Dari pendapat diatas dapat dikaji bahwa pelaksanaan dan pemberdayaan pendidikan perlu adanya dukungan dan bantuan dari pihak sekolah dan pihak luar. Sebagaimana yang dikemukakan Dirjen Pendidikan dasar dan menengah dalam Depdiknas yang melaksanakan review atau evaluasi di provinsi, kabupaten/kota adalah pengawas, staf Dinas Pendidikan yang memahami manajemen sekolah, dan para ahli atau dari pihak luar. ${ }^{17}$

Berdasarkan pendapat diatas dapat disimpulkan bahwa yang berperan dalam pelaksanaan pembelajaran dan pemberdayaan sekolah harus memerlukan dukungan dari luar sekolah itu sendiri. Sehingga dalam pemberdayaan sekolah peran Dewan Pendidikan sangat dibutuhkan baik untuk pelaksanaan penyusunan program, pelaksanaan pengajaran serta pemberdayaan lainnya. Sebagaimana menurut tugas Dewan Pendidikan adalah: a) pemberi pertimbangan dalam penentuan dan pelaksanaan kebijakan pendidikan; b) pendukung baik berwujud financial, pemikiran maupun tenaga dalam penyelenggaraan pendidikan; c) pengontrol dalam rangka transparansi dan akuntabilitas penyelenggaraan dan keluaran pendidikan; d) mediator antara pemerintah dan Dewan Perwakilan Rakyat Daerah dengan masyarakat. ${ }^{18}$

Hasil wawancara penulis kepada ketua Dewan Pendidikan Kabupaten Rejang Lebong yang berkenaan dengan pemberdayaan sekolah yaitu "Dewan

\footnotetext{
${ }^{16}$ Depdiknas, 2001, h. 1.

${ }^{17}$ Depdiknas, 2002, h. 13.

18 Departemen Pendidikan Dasar dan Menengah, Acuan Oprasional Indikator Dewan Pendidikan, Jakarta: Dirjen Dikdasmen, 2004, h. 5.
} 
Pendidikan berperan dalam pemberdayaan sekolah yakni dalam perencanaan program sekolah, hubungan sekola dengan masyarakat dan hubungan sekola dengan pemerintah.",19

Sekolah sebaiknya dalam pembuatan konsultasi dan meminta pertimbangan Dewan Pendidikan Kabupaten Rejang Lebong, misalnya dalam pemberdayaan sekolah.Menurut Efendi perkembangan sumber daya manusia melalui perluasan kesempatan untuk mendapatkan penghasilan, peluang kerja dan berusaha. ${ }^{20}$

\section{b. Peran Dewan Pendidikan dalam Perekrutan Guru dan Kepala Sekolah}

Dewan Pendidikan sangat berperan aktif dalam perekrutan guru dan kepala sekolah, sehingga Dewan Pendidikan menata dan memperhatikan keadaan guru di sekolah masing-masing sesuai dengan kebutuhan yang dibutuhkan pemerintah Kabupaten Rejang Lebong. Langkah-langkah yang dilaksanakan Dewan Pendidikan yaitu: 1) meninjau secara langsung setiap sekolah dan kinerja kepala sekolah apabila terdapat kekurangan dan kelemahan maka Dewan Pendidikan memberikan masukan kepada pemerintah untuk mengadakan tindak lanjut terhadap sekolah tersebut; 2) menerima masukan dan saran dari semua pihak yang berkenaan dengan kemajuan pendidikan dan merealisasikannya sesuai dengan kebutuhan yang dibutuhkan.

Mulyasa mengemukakan dalam pengrekrutan tenaga pendidik harus memperhatikan hal-hal sebagai berikut: 1) pengetahuan; 2) keterampilan; 3) dispilin; 4) upaya pribadi dan 5) kerukunan kerja. ${ }^{21}$

Perekrutan kepala sekolah yang diharapkan yaitu memiliki sumber daya manusia dan menjadi komponen yang paling berperan dalam meningkatkan kualitas pendidikan. Hal ini sejalan dengan ungkapan Supriadi bahwa "erat hubungannya antara mutu sekolah dengan berbagai aspek kehidupan di sekolah seperti disiplin sekolah, iklim budaya sekolah, dan menurunnya perilaku kenakalan siswa. Kepala sekolah bertanggung jawab atas pengelolaan pendidikan di sekolah yang secara langsung berkaitan dengan proses belajar mengajar di sekolah. ${ }^{22}$ Hal serupa dikemukakan PPNo. 28 tahun 1990 pasal 12 ayat 1 bahwa; "Kepala sekolah bertanggung jawab atas penyelenggaraan kegiatan pendidikan, administrasi sekolah, pembinaan tenaga kependidikan lainnya, dan pendayagunaan serta pemeliharaan sarana prasarana". ${ }^{23}$

Organisasi profesi tersebut yang sifatnya formal adalah kelompok kerja kepala sekolah. (KKKS), musyawarah kepala sekolah (MKS), Kelompok Kerja Pengawas Sekolah (KKPS), Musyawarah Guru Mata Pelajaran (MGMP),

\footnotetext{
19 Wawancara dengan Bapak Ediwirman, S.Pd., anggota DP, tanggal 12 Agustus 2015.

${ }^{20}$ Efendi, Administrasi Sekolah, Jakarta: Rosda Karya, 2000, h. 97.

${ }_{21}$ Mulyasa, Menjadi Kepala Sekolah Profesional, Jakarta: Rosda Karya,2005, h. 131.

22 Supriadi, Membangun Mutu Sekolah, Jakarta: Alfa Beta, 2001, h. 46.

23PP No. 28 tahun 1990 pasal 12 ayat 1.
} 
Persatuan Guru Republik Indonesia (PGRI), Forum Pertimbangan Guru (FPG) dan lainnya. ${ }^{24}$

\section{c. Peran Dewan Pendidikan dalam Pengadaan Sarana Pendidikan}

Sarana prasarana sekolah semua benda bergerak maupun yang tidak bergerak, yang diperlukan untuk menunjang penyelenggaraan kegiatan baik secara langsung maupun tidak langsung. Sarana prasarana meliputi semua peralatan yang langsung digunakan dalam proses pendidikan di sekolah, contoh gedung sekolah, ruangan, meja, kursi, alat peraga dan lain-lain. Prasarana meliputi komponen yang secara tidak langsung menunjang jalannya proses belajar mengajar atau pendidikan di suatu sekolah, menurut keputusan Menteri Pendidikan dan Kebudayaan Nasional, sarana kegiatan belajar terdiri dari tiga kelompok besar yaitu bangunan dan prabot, alat pelajaran yang terdiri dari buku, alat peraga, dan alat laboratorium, dan media belajar yang dapat dikelompokkan menjadi audiovisual yang meggunakan alat penampilan dan media yang tidak menggunakan alat penampilan. ${ }^{25}$

Dewan Pendidikan berperan serta di dalam pengadaan sarana dan prasarana yang dibutuhkan sekolah tidak terlepas dari kordinasi baik dalam pengajuan proposal atau bantuan yang berbentuk sarana, pemeliharaan sarana prasarana. Dalam perencanaan sarana sekolah sebelum diajukan kepada Dinas Pendidikan atau Pemerintah Kota atau Pemerintah Provinsi, sekolah yang bersangkutan harus membicarakan terlebih dahulu kepada Dewan Pendidikan. Sementara Dewan Pendidikan kabupaten Rejang Lebong memberikan pengesahan untuk ditindak lanjuti oleh Dinas Pendidikan.

Program pengadaan sarana prasarana disusun dan diusulkan pengadaan item-item sarana prasarana tersebut sesuai dengan yang direncanakan.Dalam tahap ini pula, Nampak adanya perbedaan pada masing-masing sekolah yang ada.Untuk sekolah-sekolah yang belum memiliki jaringan kerjasama dengan kalangan pengusaha dan stakeholder lainnya, maka pengadaan sarana prasarana sekolah hanya ditujukan kepada instansi pemerintah, yang dalam hal ini adalah Dinas Pendidikan dan kebudayaan Kabupaten Rejang Lebong.

Meskipun bantuan tersebut lebih ditekankan pada peningkatan sumber daya manusia (guru dan ketua Dewan Pendidikan) melalaui kelompok kerja guru (KKG) dan kelompok kerja kepala sekolah (KKKS). Dalam rincian ini alokasi pengelolaan keuangan yang bersumber dari pemerintah, pihak sekolah dapat menyisikan pengadaan alat tulis sekolah yang mana hal tersebut sebenarnya dapat dimanfaatkan untuk meningkatkan kualitas proses belajar mengajar. Dengan adanya bantuan tersebut, diakui oleh Dewan Pendidikan, dapat

\footnotetext{
24 Suyanto, Dinamika Pendidikan Nasional, Jakarta: PSAP Muhammadiyah, 2006, h. 28.

${ }^{25}$ Keputusan Menteri Pendidikan dan Kebudayaan Nasional Nomor: 079 tahun 1999.
} 
membantu atau mengatasi minimnya anggaran pembiayaan yang bersumber dari pemerintah.

Partisipasi masyarakat dan kalangan pengusaha yang terlibat dalam kepengurusan Dewan Pendidikan, misalnya menurut pengakuan Dewan Pendidikan pada sekolah yang bersangkutan, dikatakan bahwa pengadaan paving blok, perangkat computer, ruangan computer, semuanya berhasil diadakan diluar anggaran pemerintah.

Pengelolaan sarana pendidikan menurut Gunawan meliputi: a) kegiatan perencanaan pengadaan barang; b) pengadaan; c) inventarisir; d) penyimpanan; e) pemeliharaan, reabilitas dan f) penghapusan dan penyingkiran. Seluruh rangkaian kegiatan tersebut harus merupakan satu kesatuan yang harmonis/terpadu.Dalam sistematika kerjanya harus dihindarkan timbulnya kesimpangsiuran dan tumpang tindih dalam wewenang, tanggung jawab, dan pengawas menghindari timbulnya pemborosan biaya, tenaga dan waktu. ${ }^{26}$ Perencanaan perlengkapan kegiatan menurut Bafadal mencakup analisis kebutuhan, analisis anggaran, seleksi, keputusan, dan pemerolehan. Perencanaan adalah proses memikirkan dan menetapkan program pengadaan fasilitas sekolah, baik yang berbentuk sarana maupun prasarana pendidikan dimasa yang akan datang untuk mencapai tujuan tertentu, pengadaan perlengkapan adalah pengadaan barang atau perlengkapan pengadaan barang. Pengadaan merupakan segala kegiatan untuk menyediakan semua keperluan barang/benda/jasa bagi keperluan pelaksanaan tugas. ${ }^{27}$ Sejalan dengan pembicaraan di depan maka pengadaan sarana prasarana pendidikan dilakukan sebagai berikut: pertama, pengadaan tanah. Untuk pengadaan tanah dapat dilaksanakan dengan cara membeli, menerima hibah, menerima hak pakai atau menukar. Kedua, pengadaan bangunan. Untuk pengadaan bangunan ini dapat dilaksanakan dengan membangun baru, membeli, menyewa, menerima hibah atau menukar, (Pada prinsipnya sama dengan pengadaan tanah). Ketiga, pengadaan perabot.Cara pengadaan perabot dapat dilakukan membeli, membuat sendiri, atau menerima bantuan/sumbangan.Keempat, pengadaan kendaraan/alat tranportasi.Yang dimaksud dengan kendaraan adalah alat angkut orang atau barang untuk didarat, diair, dan di udara.Khusus untuk sekolah hanya kendaraan darat dan air.Kendaraan dapat dibedakan kendaraan bermotor (mobil, sepeda, motor, kapal motor, dan sebagainya).Dewasa ini pengadaan kendaraan untuk sekolah telah dilakukan oleh pemerintah pusat.Kelima, pengadaan sarana pendidikan, alatalat kantor dan alat tulis kantor (ATK). Sarana pendidikan (alat pelajaran, alat peraga, media, dan alat-alat praktikum), alat-alat kantor (mesin ketik, mesin hitung, mesin stensil, alat penyedot debu, sapu, dan lain sebagainya) dapat

\footnotetext{
${ }^{26}$ Gunawan, Sarana dan Prasarana Pendidikan, Jakarta: Sinar Mas, 1998, h. 89.

27 Bafadal, Pasilitas dan sarana Pendidikan, Jakarta: Rosda Karya, 2006, h. 15.
} 
dibedakan sesuai dengan ketentuan yang berlaku yaitu untuk jumlah besar melalui lelang/tender dengan rekanan. Kekurangan alat tulis kantor (ATK) dalam jumlah kecil dapat diadakan pembelian melalui dana taktis. Pengadaan buku-buku atau benda grafis lainnya dapat diadakan dengan membuat sendiri, menerima bantuan hadiah, hibah, inventarisir adalah kegiatan inventarisir.Inventarisir yaitu kegiatan mencatat dan menyusun daftar barang milik Negara secara sistematis dan secara teratur berdasarkan ketentutan atau pedoman yang berlaku. Kegiatan tersebut memerlukan beberapa buku yang harus diadakan, antara lain buku penerimaan barang, buku pembelian barang, buku inventaris, buku bukan inventaris, dan buku atau kartu stock barang. ${ }^{28}$ Kegiatan inventaris adalah pencatatan pemberian nomor kode atau nomor inventaris dan pencatatan kedalam buku induk barang atau buku inventaris. Waktu terjadi proses pengadaan barang seharusnya telah dipikirkan pula masalah tempat penyimpanan, agar jangan sampai terjadi perlengkapan yang baru kita beli tidak mendapatkan tempat.

\section{d. Peran Dewan Pendidikan dalam Peningkatan Kerja Sama Masyarakat, Pemerintah dan Lembaga Pendidikan}

Keberadaan Dewan Pendidikan untuk meningkatkan tanggung jawab dan peran serta aktif dari seluruh lapisan masyarakat dalam menyelenggarakan pendidikan, serta menciptakan suasana dan kondisi transparans, akuntabel, dan demokratis dalam penyelenggaraan serta pelayanan pendidikan yang bermutu disatuan pendidikan.Lembaga-lembaga pendidikan diharapkan mampu mengganti berbagai peran yang dulunya dipegang oleh pemerintah sepenuhnya.Dengan demikian pengelolaan sekolah bisa lebih partisispatif, terbuka, akuntabel dan mencerminkan kebutuhan masyarakat umum. ${ }^{29}$

Sehingga pemerintah melalui Dewan Pendidikan dapat menerima, menyampaikan aspirasi pemerintah dan masyarakat untuk memperlancar proses pendidikan dimasa-masa yang akan datang. Disamping itu keberadaan Dewan Pendidikan bisa menekan berbagai penyimpangan terutama keuangan yang menyebabkan mahalnya biaya sekolah serta dapat memberikan masukan atas partisipasi dan ikut serta dalam kemajuan pendidikan, peran Dewan Pendidikan merupakan peran yang legal yang bukan hanya melaksanakan protes, usul yang tidak bisa dipertanggungjawabkan. Karena lembaga ini dibentuk untuk menilai, menimbang pekerjaan Dewan Pendidikan, Lembaga Sekolah dalam memajukan pendidikan yang diharapakan.

Masyarakat itu kenyataannya sangat kompleks dan tidak memiliki batas yang jelas, sehingga sulit menentukan masyarakat yang mana sebagai stake-holder di bidang pendidikan. Salah satu cara memfungsikan masyarakat sebagai

\footnotetext{
${ }^{28}$ Kristina, Administrasi Kantor, Jakarta: Alfa Beta, 2007, h. 30.

${ }^{29}$ Tirani, Adminstrasi Sekolah, Jakarta: Rosda Karya, 2006, h. 106.
} 
stakeholder tersebut adalah dengan menggunakan prinsip perwakilan, yaitu memilih sejumlah kecil dari seluruh anggota masyarakat untuk melaksanakan fungsi-fungsi control pemberi masukan, pemberi dukungan, serta fungsi mediator antara masyarakat dengan lembaga-lembaga pendidikan. Fungsi-fungsi tersebut di tingkat kabupaten/kota dilakukan Dewan Pendidikan, dengan demikian Dewan Pendidikan adalah badan yang mewadahi peran serta masyarakat dalam rangka meningkatkan mutu, pemerataan, dan efisiensi pengelolaan pendidikan di kabupaten/kota.

\section{Kesimpulan}

Penelitian ini menyimpulkan bahwa peran Dewan Pendidikan dalam meningkatkan mutu pendidikan di Kabupaten Rejang Lebong adalah sebagai berikut: (a) pemberi pertimbangan dalam penentuan dan pelaksanaan kebijakan pendidikan, (b) pendukung baik berwujud financial, pemikiran maupun tenaga dalam penyelenggaraan pendidikan, (c) pengontrol dalam rangka transparansi dan akuntabilitas penyelenggaraan dan keluaran pendidikan, (d) mediator antara pemerintah dan Dewan Perwakilan Rakyat Daerah (DPRD) dengan masyarakat.

Dewan Pendidikan seharusnya dapat meningkatkan mutu pendidikan, memotivasi pihak sekolah untuk meningkatkan mutu pendidikan, dengan jalan meningkatkan kerjasama dengan diknas melalui perantara Dewan Pendidikan. Pemerintah daerah umumnya dan pemerintah Kabupaten Rejang Lebong khususnya dapat merealisasikan upaya Dewan Pendidikan secara menyeluruh, sesuai dengan peraturan pemerintah yang telah ditetapkan, pemerintah harusnya memperhatikan kebutuhan pendidikan dimasa sekarang dan akan datang baik berupa bantuan fisik maupun bantuan non fisik. Semoga seluruh lapisan masyarakat dapat mendukung jalannya pendidikan demi kemajuan bersama untuk mewujudkan cita-cita bangsa dan negara serta keluarga.

\section{Daftar Pustaka}

Albert Shuster, 1998, Administrasi sebagai Seni dan Ilmu, Jakarta: Logos.

Bafadal, 2006, Pasilitas dan sarana Pendidikan, Jakarta: Rosda Karya.

Burhanuddin, Yusak, 1998, Administrasi Pendidikan, Bandung: Pustaka Setia.

Dedi Supriadi, 2002, Otonomi Daerah dan Pendidikan, Materi Seminar Pendidikan.

Departemen Pendidikan dan Kebudayaan, Peraturan Pemerintah, No. 39 tahun 1992.

Departemen Pendidikan Dasar dan Menengah, 2004, Acuan Oprasional Indikator Kinerja Komite Sekolah, Jakarta: Dirjen Disdasmen.

Departemen Pendidikan Dasar dan Menengah, 2004, Acuan Oprasional Indikator Dewan Pendidikan, Jakarta: Dirjen Dikdasmen.

Drury dan Levin, 2001, Manajemen Berbasis Sekolab, Jakarta: Rineka Cipta.

Edward Sallis, 1999, Total Quality Education (TQE), Jakarta: Logos.

Efendi, 2000, Administrasi Sekolah, Jakarta: Rosda Karya.

Fulan, 1997, Peranan Kepala Sekolah, Bandung: Pustaka Setia. 
56 | TADBIR : Jurnal Studi Manajemen Pendidikan, Vol. 3, No. 1, Mei 2019

Gunawan, 1999, Kepemimpinan dan Administrasi Pendidikan, Yogyakarta: UII Press.

Gunawan, 1998, Sarana dan Prasarana Pendidikan, Jakarta: Sinar Mas.

Hamidi, 2004, Mengola Data Penelitian, Jakarta: Bumi Aksara.

Harsimi Arikunto, 2002, Pedoman Wawancara, Jakarta: Rineka Cipta.

Indra Jati Sidi, 2002, Menuju Masyarakat Belajar: Menggagas Paradigma Baru Pendidikan, Jakarta: Alfa Beta.

Kepmendiknas Nomor. 044/U/2002 tentang Dewan Pendidikan.

Keputusan Mendiknas RI Nomor: 044/UU/2002 tentang Dewan Pendidikan dan Komite Sekolah.

Keputusan Menteri Pendidikan dan Kebudayaan Nasional Nomor: 079 tahun 1999.

Kristina, 2007, Administrasi Kantor, Jakarta: Alfa Beta.

Margono, 2005, Metodologi Penelitian Kuantitatif, Jakarta: Rineka Cipta.

Muhadjir, 2002, Penelitian Kualitatif dan Kuantitatif, Jakarta: Logos.

Mulyadi, 1999, Pedoman Wawancara, Bandung: Sinar Mas.

Mulyasa, 2005, Menjadi Kepala Sekolah Profesional, Jakarta: Rosda Karya.

Nasution, 2002, Azas-azas Kurikulum, Jakarta: Bumi Aksara.

Nawawi dan Asmara Handari, 2000, Administrasi Sekolah yang Berdaya Guna, Surabaya: Sinar Mas.

Pasli Jalal dan Dedi Supriadi, 2004, Meningkatkan Mutu Pendidikan, Jakarta: Rosda Karya.

PP No. 28 tahun 1990 pasal 12 ayat 1.

Roel Jhones dan Edgar L. Morphet, 1997, Education Leadership and Mangemen, London: Letters.

Sagala, Syaiful, 2005, Manajemen Strategik dalam Peningkatan Mutu Pendidikan, Jakarta: Alfa Beta.

Satori dan Fattah, 2006, Otonomi Pendidikan, Jakarta: Grasindo.

Siwojo, 2005, Pendidikan Bermutu dan Ideal, Jakarta: Radar Jaya.

Stepen J. Knezevich, 1994, Administration of Public Education, London: Education Press.

Subagio, 2004, Metodologi Penelitian: Dalam Teori dan Praktek, Jakarta: Rineka Cipta.

Sudjana dan Sudjarat, 2001, Penelitian Kualitatif, Jakarta: Alfa Beta.

Supriadi, 2001, Membangun Mutu Sekolah, Jakarta: Alfa Beta.

Surakhmand, 2000, Teknik Pengumpulan Data Penelitian, Jakarta: Alfa Beta.

Suyanto, 2006, Dinamika Pendidikan Nasional, Jakarta: PSAP Muhammadiyah.

Syarafuddin, 2006, Manajemen Mutu Terpadu dalam Pendidikan, Jakarta: Grasindo.

Tirani, 2006, Adminstrasi Sekolah, Jakarta: Rosda Karya.

Undang-undang No. 20 tahun 2003 Sistem Pendidikan Nasional, pasal 1 ayat 2.

Undang-undang No. 25 tahun 2000, tentang Peran Pemerintah dalam Pendidikan. 
Undang-Undang Nomor: 22 Tahun 1999 tentang Pemerintah Daerah. UU No. 25 tahun 2000 tentang program pembangunan nasional. 